\title{
The Situation of Lifelong Education in Turkey*
}

\section{Alaattin GÜLMEZ¹, Osman TİTREK ${ }^{2}$, M. Ali ÖZKORKMAZ ${ }^{3}$}

\author{
${ }^{1}$ School Principles in Hendek - alaattingulmaz77@hotmail.com \\ ${ }^{2}$ Assoc. Prof. - otitrek@sakarya.edu.tr \\ 3Teacher, Ministry of National Education - maliozk@hotmail.com \\ *This paper presented at "1st International Conference on Lifelong Education and Leadership for
}

ALL-ICLEL2015".

\begin{abstract}
The life of individual's after formal education, to acquire the knowledge and skills that our time require for the people who didn't get the formal education can be possible through non-formal education. Therefore, the importance of non-formal education has begun more and more important recently. The aim of this research is to examine the condition of public education centers, to identify the problems and find solutions to them. In this research, priority, the conditions of public education centers have been identified. Also, the structures of the courses and trainees and their distribution across the country, the courses and their features, the features of the trainers who have worked in these courses have been analyzed. Secondly; the problems of public education and the issue of how can these problems be solved emphasized.
\end{abstract}

Keywords: Non Formal Education, Public Education, Adult Education

\section{Introduction}

There are two dynamics which affect a country's development: These are education and economics. Whether to achieve it or not depends on the effect of these two dynamics back each other up. It has become an inevitable necessity to gain and maintain the necessary qualifications of economics not only at a definite time but also to renovate the power of humans. In this context; the most appropriate institutions that complement existing applications are the formal education institutions. Whether non formal education is in a developed country or in a developing country it is still an important issue to achieve better life standards. Because one of the most important dynamic of development is change and progress is the well trained manpower. But, it is sometimes impossible to educate the people. Today; it seems impossible to solve the problems of changing social and individual needs of the people with the current Turkish education system. (formal and non-formal education)The new studies which will be conducted in the field of education especially vocational social and technical are vital (Özoğul, 2003). Non formal education can't maintain development and progress functionally. The thing that develops and solve to problems is analytical thinking individually. The analytical thinking person is someone has been educated according to his/her affective and cognitive abilities. Non -formal education is a program which complements the requirements of the formal training it supports the interests and skills of the people. Our era is an era of change and the rapid development of science and technology invalidate the information that is given in formal education institutions in a short time. To renew the profession for various reasons, to gain new profession, to complete the deficiencies of formal education, to evaluate leisure time in old age, to gain the behavior required for progress increase the need for non-formal education (Fidan, 1996). In this study the conditions of public education centers, opened courses, numerical data of the courses, distribution across the country, the structure of the staff in public education centers, the education level of the trainees are emphasized and tried to find solutions to them.

\subsection{The Concepts Related to the Subject}

Non formal education is a wide subject. There are some words which are used as synonyms but have different meanings. Therefore, in order not to create chaos, the concepts have been analyzed one by one. Non formal education covers everything that is organized within the formal education. There isn't an age limit in non-formal education. It can be done for any age. (child, young, adult etc.) (Fidan and Erdem, 1991). Another definition of non-formal education is that it is an education given for the people who did not take any facilities of formal education or for those who had to leave school of for those who are going 
to formal schools or for those who want to become more efficient in their profession (Demirel, 1987). The most comprehensive organized form of public education is non-formal education. It is education and training activities to increase the operating power of citizens to increase the quality of life. It is given inside or outside of the training centers (Demirel, 1987). Public education not only aims to increase the vocational qualifications of the people but also aims to increase the vocational qualifications of the people but also aims to ensure the cohesion of the people so that it allow the transfer of the culture to the new generation.

According to the definition made by UNESCO; it is an education provided for the people who are aged fifteen and beyond. It is also an education system for the people who are outside the normal school and university systems and it is organized according to the needs (Lowe; cited. Oğuzkan, 1985).According to the definition made by the Ministry of Education; it is a guidance and implementation actions for those who have never entered the formal education system or located in any stage separated from the stage or graduated. It provides cultural development and lasts life-long (MEB 2014). The concept of adult education is defined in different ways by different thinkers. Some thinkers define public education as an adult education which must be conducted for those who are outside the education. The other thinkers define it as an education that helps to the development of human i. According to this definition, adult education must meet the requirements of public education and must give the skills and knowledge they need. It must enhance their experience and must help to find solutions to their mutual problems. When we look in more depth the necessity of adult education is a result of the differences in the economical social and political structures (Aziz, 1975: 20-21).

\subsection{The Principles of Public Education}

According to the Common Regulation for Instructional Institutions of Ministry of Education, the common aims of Ministry of Education, basic principles of non-formal education are like this (MEB, 2014). All the training courses by the national education are performed in accordance with these principles: For the benefit of everyone and according to the conditions of the world. It is planned and open to innovation and progress. Everybody can benefit from it for free voluntarily. It can be conducted at every time at everywhere. It covers the formal and non-formal education.

\subsection{The Goals of Public Education}

In the light of the principles mentioned above, according to Turkish Education system the purpose and function of Non Formal Education Constitution ; the general aims and principles of Turkish National Education ; in the direction of Atatürk's principles and reforms, universal law, to strenght national integration and provide to do your civic duty to teach read and write, to prepare education facilities in order to complete their missing training to prepare education opportunities which are adoptive to our age of scientific, technological, economic, social and cultural development when the facilities are convenient to spread common training in abroad using information technology, to prepare and implement programs for the Turkish Republic and Turkish communities with other countries to teach Turkish in a correct and effective way, to prepare studying abroad programs within the framework of bilateral agreements , to provide local public and private resources in the development of society to organize social activities for the success of their educational projects and to join such activities, the protection of national cultural values, to gain the habits of living collective, solidarity, assistance, to help introduce the new technologies in agriculture, industry and in the service sector, to develop new service areas to help employees gain the skills for a better life, to make studies according to education, production, employment, marketing, to make studies for the people who migrate from rural areas to adopt them to the city culture, to cultivate a work force with the needs of the industry, to conduct vocational and technical studies, to provide in-service training for their vocations in order to advance in various jobs providing necessary information and skills, protecting health institutions and experts, family planning, civil defence, healthy nutrition and housing, to make studies to be a better manufacturer and consumer, to provide exhibiting talents and develop opportunities, to teach reading and writing according to their requiring special education, complete their training and to gain knowledge and skills (MEB 2014) .

\section{Method}

This study conducted on survey method based on literature review. Based on the literature, in this study, government data's were used to explain the situation lifelong education institutions in Turkey. Later on, some suggestions has written to the researcher to develop lifelong education system. 


\section{Results}

In Table 1, you can see current numbers of trainer's attending LLE courses in Turkey.

Table 1. Number of attending and graduate trainees by SRE 3Level 3 and educational institutions

\begin{tabular}{|c|c|c|c|c|c|c|c|c|}
\hline \multirow{2}{*}{$\begin{array}{l}\text { Educational } \\
\text { institutions }\end{array}$} & \multicolumn{3}{|c|}{ Attending trainee } & \multicolumn{5}{|c|}{ Age groups of trainee attended LLE courses } \\
\hline & Total & Male & Female & $0-5$ & 6-14 & $15-22$ & $23-44$ & $45+$ \\
\hline \multicolumn{9}{|l|}{$\begin{array}{l}\text { End of the } \\
\text { Educational Year } \\
2011 / \text { '12 }\end{array}$} \\
\hline Overall of Turkey & $\begin{array}{l}7856 \\
340\end{array}$ & $\begin{array}{l}3801 \\
144\end{array}$ & $\begin{array}{l}4055 \\
196\end{array}$ & 48292 & 1895042 & 2492431 & 2389525 & 964379 \\
\hline $\begin{array}{l}\text { Public Education } \\
\text { Center }\end{array}$ & $\begin{array}{l}4256 \\
506\end{array}$ & $\begin{array}{l}1553 \\
098\end{array}$ & $\begin{array}{l}2703 \\
408\end{array}$ & - & 1197824 & 851487 & 1379518 & 827677 \\
\hline $\begin{array}{l}\text { Vocational Training } \\
\text { Center }\end{array}$ & $\begin{array}{l}261 \\
963\end{array}$ & 210669 & 51294 & - & - & 145128 & 111396 & 5439 \\
\hline $\begin{array}{l}\text { Vocational Courses } \\
\text { Opened in the } \\
\text { Scope of } 3308\end{array}$ & $\begin{array}{l}66 \\
444\end{array}$ & 48387 & 18057 & - & 158 & 19918 & 38404 & 5163 \\
\hline $\begin{array}{l}\text { Girls Technical } \\
\text { Educational } \\
\text { Institute }\end{array}$ & 1780 & 14 & 1766 & - & - & 369 & 925 & 256 \\
\hline $\begin{array}{l}\text { Tourism Education } \\
\text { Center }\end{array}$ & 1096 & 892 & 204 & - & - & 1026 & 63 & 7 \\
\hline $\begin{array}{l}\text { Adult Technical } \\
\text { Training Center }\end{array}$ & - & - & - & - & - & - & - & - \\
\hline Private Tutoring & $\begin{array}{l}1280 \\
297\end{array}$ & 644059 & 636238 & - & 511172 & 738480 & 30271 & 374 \\
\hline $\begin{array}{l}\text { Private Motor } \\
\text { Technical }\end{array}$ & $\begin{array}{l}1387 \\
422\end{array}$ & $\begin{array}{l}1001 \\
330\end{array}$ & 386092 & - & - & 610538 & 664725 & 112159 \\
\hline Courses & & & & & & & & \\
\hline $\begin{array}{l}\text { Various Private } \\
\text { Courses }\end{array}$ & $\begin{array}{l}285 \\
026\end{array}$ & 157377 & 127649 & 426 & 4885 & 66391 & 137199 & 12485 \\
\hline $\begin{array}{l}\text { Special Education } \\
\text { and Rehabilitation }\end{array}$ & $\begin{array}{l}262 \\
818\end{array}$ & 155503 & 107315 & 44051 & 139504 & 53216 & 25261 & 786 \\
\hline $\begin{array}{l}\text { Private Education } \\
\text { School } \\
\text { (non-formal) }\end{array}$ & $\begin{array}{l}20 \\
108\end{array}$ & 12116 & 7992 & 3160 & 10873 & 4316 & 1735 & 24 \\
\hline $\begin{array}{l}\text { Special Study } \\
\text { Training Center }\end{array}$ & $\begin{array}{l}21 \\
612\end{array}$ & 11587 & 10025 & 655 & 20658 & 262 & 28 & 9 \\
\hline $\begin{array}{l}\text { Science and Arts } \\
\text { Center (Gifted and } \\
\text { Talented Students) }\end{array}$ & $\begin{array}{l}11 \\
268\end{array}$ & 6112 & 5156 & - & 9968 & 1300 & - & - \\
\hline
\end{tabular}

Resources. TÜIIK, NON FORMAL EDUCATION ACTIVITIES RESEARCH, 2009-2013

There has been seen an increase in the number of educational centers. There was a little increase from 1999-2000 to 2005-2006. There were 925 public education centers in 2005-2006. There were 934 in 2006-2007. There were 957 in 2007-2008 and 969 in 2008-209. There was a great increase among 2005-2012. There wasn't an increase among 2009-2011. It was 980 in 2011-2012. There was a little increase and became in 2012-2013.

When we look at the Table 1 education centers provide $\% 54,18$ of the people who benefit from it. After education centers $\% 17,65$ from private motor vehicle driving course and \% 16,29 from private courses. The number of male trainees is \% 48and \% 51, 62 are women $\mathrm{n}$ Turkey. The number of male trainees are $\% 48$ and \% 51,62 are women in Turkey. THA number of male who benefit from public education centers is $\% 36,48$, female trainees are $\% 63,52$. The number of male trainees benefitting from motor vehicle course is $\% 72,17$, female trainees are $\% 27,83$. While there are female trainees in public education centers, there are more male trainees in private motor vehicle driving courses. In private courses the number is fifty. $\% 50,30$ is male and $\% 49,70$ is female. Considering the age group in Turkey $\% 0,61$ is 
between 0-5 age, \%31,72 is 6-14 age, \%30,41 23-44, \% 12, 27 is $45+$. In public education centers there are no trainees between $0-5, \% 28,14$ is $15-22, \% 32,40$ is between $23-40$ and \% 19,44 is $45+$.More than $\% 60$ is between $15-44$. In public education centers $15-44$ group is $\% 52$. Also, the $\% 96,61$ of the trainees has completed their courses in public education centers.

Table 2. Number of participants by Classification of Regional Units Level 1 and Educational Institutions (End of the educational year 2011/ '12)

\begin{tabular}{|c|c|c|c|c|c|c|}
\hline Educational institutions and SRE-Level 1 & 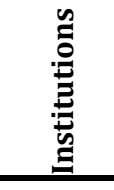 & 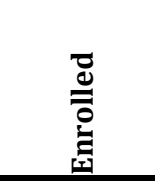 & 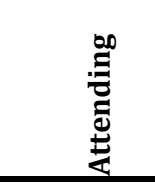 & 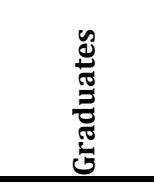 & 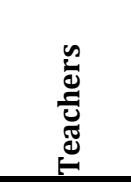 & 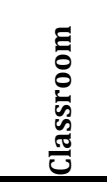 \\
\hline Turkey & 13732 & 8071508 & 7856340 & 7789669 & 111274 & 85540 \\
\hline Public Training Centers & 981 & 4405603 & 4256506 & 4256506 & 6175 & 3474 \\
\hline Vocational Training Centre & 314 & 261963 & 261963 & 261963 & 4426 & 2186 \\
\hline Vocational Courses Offered Under 3308 & - & 73083 & 66444 & 63643 & - & - \\
\hline Institute of Technical Education for Girls & 15 & 2488 & 1780 & 1550 & 511 & 133 \\
\hline Tourism Training Center & 9 & 1096 & 1096 & 1096 & 101 & 51 \\
\hline Adults Technical Education Center & 12 & - & - & - & - & - \\
\hline Private Courses & 3858 & 1280297 & 1280297 & 1280297 & 51522 & 39867 \\
\hline Private Motor Vehicle Driving School & 3301 & 1387422 & 1387422 & 1387422 & 22490 & 7947 \\
\hline Private Various Courses & 2438 & 343750 & 285026 & 221386 & 6452 & 9724 \\
\hline \multicolumn{7}{|l|}{ Special Education and Rehabilitation Center } \\
\hline Special Education School & 152 & 20108 & 20108 & 20108 & - & - \\
\hline Special Study Training Center & 677 & 21612 & 21612 & 21612 & 1520 & 1966 \\
\hline \multicolumn{7}{|l|}{ Private Preliminary Study Education Center } \\
\hline Guidance and Research Center & 218 & - & - & - & 2332 & 47 \\
\hline Science and Arts Center Gifted or (talented) & 66 & 11268 & 11268 & 11268 & 669 & 685 \\
\hline
\end{tabular}

Resources. TÜIKK,NON FORMAL EDUCATION ECTIVITIES RESEACRH, 2009-2013

When we investigate Table 2, it seems that the number of non-formal education activities' \% 7,13 belong to public education centers, $\% 28,09$ belong to private courses, $\% 24,03$ belong to private motor vehicle courses, \% 17,75 belong to private courses, \%4, 93 private training center. Looking at the number of institutions, the number of Institution of public education center is fairly low. Considering the number of participants, the number of graduates \% 54,64 belong to public education centers, \% 15,86 belong to private tutoring, \% 17,18 belong to private motor vehicle courses and \% 0,26 belong to private study centers. Considering the rate of classes \% 4,06 belongs to public education centers, $\% 46,60$ belong to private tutoring, $\% 9,29$ belong to the private motor vehicle courses, $\% 22,74$ belong to special education and rehabilitation centers, $\% 2,29$ belong to private study centers. Considering the rate of trainees who benefitted from formal education activities; \%54,64 belong to public education centers, $\% 15,86$ to private tutoring, \%17,18 to private motor vehicle courses, \%2,26 to private study centers. Considering the number of instructors taking part in these courses; \% 5,64 public education centers, \% 15,86 belong to private tutoring, \% 17,18 belong to private motor vehicle courses, $\% 2,26$ belong to private study centers. Considering the number of instructors taking part in these courses, \% 5,54 public education centers, $\%$ 46,30 Private tutoring, \% 20,21 private motor vehicle courses, \% 13, 54 special education and rehabilitation centers, \%1,36 private study centers. The number of trainers per class for the public education centers is 1,7, 1,29 for special education and rehabilitation centers, 1,29 private tutoring centers,2,82 private centers, 49,61 private study centers. The general number for Turkey is 1.30 . The number of trainees per classroom in public education centers is 1268,32 trainees for private tutoring, 174 trainees in private motor vehicle courses,13 students for special education and rehabilitation centers, 10 students for private study centers. The generalization is 91 trainees in Turkey. The number of trainees per classroom in public education centers is fairly high. 
Table 3. The number of public education centers have been continuing and graduating since 2013

\begin{tabular}{lcccc}
\hline REGIONS & $\begin{array}{c}\text { The rate of courses } \\
\text { opened in the } \\
\text { regions }\end{array}$ & $\begin{array}{c}\text { Proportion of } \\
\text { participants attending the } \\
\text { courses }\end{array}$ & $\begin{array}{c}\text { Course } \\
\text { completion } \\
\text { rates }\end{array}$ & $\begin{array}{c}\text { The rate of the } \\
\text { countr's populationı }\end{array}$ \\
\hline $\begin{array}{l}\text { Mediterranean } \\
\text { Region }\end{array}$ & 11.91 & 9.7 & 9.27 & 12.8 \\
$\begin{array}{l}\text { East Anatolia } \\
\text { Region }\end{array}$ & 5.34 & 3.54 & 3.71 & 6.6 \\
$\begin{array}{l}\text { Aegean Region } \\
\text { Southeast }\end{array}$ & 10.45 & 8.37 & 8.66 & 12.7 \\
Anatolia & 6.63 & 6.44 & 6.71 & 10.2 \\
Center Anatolia & 19.26 & 26.6 & 27.27 & 15.9 \\
Black Sea Region & 11.38 & 6.01 & 6.31 & 9.6 \\
MARMARA & 35.03 & 39.34 & 38.07 & 32.2 \\
Region & 100 & 100 & 100 & 100 \\
Total Ratio & 100 & & \\
\hline
\end{tabular}

Resources. TÜIK, NON FORMAL EDUCATION ACTIVITIES RESEARCH, 2009-2013

When we look at the Table 3 we see great differences with the courses, attending and graduate trainees in Turkey general. The figures seem higher in the regions that have developed in terms of industry than the other regions. Considering the figures in terms of regions, the number of opened courses are like this: \% 1,91 Mediterranean Sea, \% 5,34 East Anatolia, \% 10,45 Aegean Region, \% 63 Southeast Anatolia, \% 19, 26 central Anatolia, \% 11,38 black Sea, \% 35,03 Marmara Region. When we look at the figures it is obvious that 3/1 of the courses are in Marmara Region. The multiply figures of East Anatolia, southeast, Black Sea and Mediterranean don't make as much as Marmara Region.

Considering the Table 3 attending trainees are like this: \% 9,7* Mediterranean, \%3,54 East Anatolia \%8,37 Aegean, \% 6,4 Southeast, \%26,60 Central Region, \%6,01 Black sea, \% 39,34 Marmara Region. The figures show that more trainees are attending the courses in Marmara and but the number of attending trainees getting less in other regions. When we look at the number of graduates $\% 9,27$ Mediterranean $\%$ 3,71 East Anatolia, \% 8, 6 Aegean, \% 6,71 Southeast region, \%27,27 Central Region, \%6, 31 Black Sea, \%38, 07 Marmara Region. Seeing the figures; there is an increase in terms of graduates an Marmara and Central Anatolia Regions, also there is a reduction in the other regions. When we look at the table, the number of courses opened in Marmara, Black sea and Central Anatolia are higher than the population of the country. There are less courses than the population of the country in Black sea, the attending and graduate trainees are less. Considering Turkey in general, in every region in two or more cities the number of trainees are more or the same than in the other regions. When we look at the regions while the courses are more the attending trainees are les, the attending trainees are more and the courses are less. In Mediterranean region, there are 2969 courses in Antalya 232 in Adana. The number of trainees in Antalya is 137216 and 4585 in Adana and 41712 in Mersin. Antalya is much further than the other cities in terms of trainees. The total number of trainees is 137216 since 2013. The total number is 174036 in the region. Malatya has got 723 trainees, 523 in Erzurum and 432 in Van. Van is at the top in terms of trainees numbering 28689 and Erzurum is second with 19284, Malatya 17883 according to the data in 2013.

In Aegean region there are 2622 courses in İzmir 1350 in Muğla, 984 in Manisa. In terms of trainees there are 132928 in İzmir, 36818 in Manisa, 30937 in Muğla. The \% 34,68 of the courses and \% 45,96 of trainees belong to İzmir. According to the data in 2013 in Southeast Anatolia there are 1014 courses in Gaziantep 819 courses in Şanlıurfa and 632 in Diyarbakır. Looking at the number of traines there are 81764 in Diyarbakır, 36731 in Şanlıurfa 350 in Gaziantep. Although \% 21, 13 of the courses are in Gaziantep, the number of trainees are just \% 15,8. Even though \% 13,17 of the courses are in Diyarbakır , the trainees make \% 36,37 of it. According to the data in 2013 in central region, there are 8651 courses are in Ankara 65916 in Konya, 59514 in Eskişehir. The \% 62,12 of the courses and \% 73 ,54 of the trainees belong to Ankara. According to the data in 2013, Black sea, there are 104 courses in Samsun, 953 in Trabzon,621 in Çorum. In terms of trainees there are 29604 in Trabzon, 28646 in Zonguldak, 21313 in Samsun. According to the data in 2013 in Marmara region, İstanbul is in the first place with 17808 courses, Bursa is in the second place with 2039, Sakarya is in the third place with 1248. Considering the 
number of trainees İstanbul is in the first place with 1031793, Bursa is second with 121675, Kocaeli is third with 73778. İstanbul itself has got the \% 70,30 of the courses and 576,60 of the trainees.

At the same time; \% 40,21 of the courses opened in Turkey belong to İstanbul Ankara and İzmir and \% 53,74 of the trainees belong to that three cities. The rate of that three cities is $\% 30,42$. İstanbul itself has got \% 24 of the courses and \%30,21 of the trainees. The population of istanbul is \% 18,50 in Turkey. When we lok at the overall of Turkey, the fewest courses are opened in Tunceli, Iğdır, Ardahan, Karaman, Kırşehir, Bayburt,Erzincan, Bitlis and Hakkari.

Table 4. Education level of graduates by SRE Level 3 and educational institutions

\begin{tabular}{|c|c|c|c|c|c|c|c|c|}
\hline $\begin{array}{c}\text { End of the educational } \\
\text { year } 2012 / \\
\text { '13Educational } \\
\text { institutions } \\
\end{array}$ & & & & Education & evel & & & \\
\hline & Illiterate & Literate & $\begin{array}{l}\text { Primary } \\
\text { school }\end{array}$ & $\begin{array}{c}\text { Primary } \\
\text { education }\end{array}$ & $\begin{array}{l}\text { General } \\
\text { high } \\
\text { school }\end{array}$ & $\begin{array}{l}\text { Vocational } \\
\text { High School }\end{array}$ & $\begin{array}{l}\text { High } \\
\text { school }\end{array}$ & Total \\
\hline TR Turkey-Total & 245231 & $\begin{array}{l}823 \\
567\end{array}$ & $\begin{array}{c}1188 \\
189\end{array}$ & 2348935 & 2292699 & 476377 & $\begin{array}{l}863 \\
655\end{array}$ & $\begin{array}{c}8238 \\
653\end{array}$ \\
\hline Public Education center & 126756 & $\begin{array}{l}821 \\
685\end{array}$ & 702934 & 1047329 & 1022271 & 189495 & $\begin{array}{l}501 \\
062\end{array}$ & $\begin{array}{c}4411 \\
532\end{array}$ \\
\hline
\end{tabular}

Resources. TÜIK, NON FORMAL EUCATION ACTIVITIES RESEARCH 2009-2013

When we investigated Table 4, \% 2,97 of the people benefitting from non formal education ,illiterate , $\%$ 10,00 of them are literate, $\% 14,43$ are collage graduates. The majority of them consist of primary school graduates and high school graduates. $\% 2,87$ of the people benefitting from public education centers are illiterate, $\% 18,63$ of them are literate $\% 15,94$ of them are primary school, $\% 23,74$ are primary education, $\% 23,17$ are high school, $\% 4,29$ are vocational high school, $\% 11,36$ are college graduates. As we can see the numbers of literate trainees are more in public education centers. In the scope of non-formal education activities; 72321 courses were conducted in 2013. In the research the ministry and agencies, universities, municipality, confederation, union, foundation and associations were covered in this context. 72321 courses were conducted. The number of attending trainees is 3 million 415233 and graduates are 3 million 294418.

Table 5. Formal education activities provided by Institutions and Organizations by 2012-2013

\begin{tabular}{lcccccc}
\hline & \multicolumn{2}{c}{ Number of courses } & \multicolumn{2}{c}{ The number of participants } & \multicolumn{2}{c}{ Graduates } \\
Institution and organization & $\mathbf{2 0 1 2}$ & $\mathbf{2 0 1 3}$ & $\mathbf{2 0 1 2}$ & $\mathbf{2 0 1 3}$ & $\mathbf{2 0 1 2}$ & $\mathbf{2 0 1 3}$ \\
\hline Total & 77715 & 72321 & 3299563 & 3415233 & 3095003 & 3294418 \\
Ministries and organizations & 50003 & 47104 & 1253043 & 1231862 & 1206601 & 1228909 \\
University & 3203 & 3805 & 232353 & 258860 & 228207 & 255596 \\
Municipality & 16169 & 15841 & 763044 & 971847 & 658332 & 865220 \\
Confederation and union & 685 & 276 & 154541 & 101536 & 154346 & 101378 \\
Foundations and Associations & 7655 & 5295 & 896582 & 851128 & 847517 & 843315 \\
\hline
\end{tabular}

Resources. TÜIIK, NON FORMAL EUCATION ACTIVITIES RESEARCH 2009-2013

When we look at the table 5 we see a decline of $\% 6.9$ in the number of courses opened by institutions in 2013 in comparison with the ones opened in 2013565,1 of the courses conducted by ministries and associated institutions \% 21,9 by municipalities, \% 7,3 by foundations and associations, \%5, 6 by other institutions and organizations. \% 93,8 of the people participated in the non-formal education activities, completed education in 2012, moreover; it rose to \% 96,5 in 2013. \% 37,3 of the people completed courses conducted by the ministries and associated institutions, $\% 26,3$ of the people by the municipalities, \% 25,6 by the foundations and associations. In the scope of the principles and goals mentioned above; generally these activities and courses in non-formal education stand out in Turkey: Literary courses, vocational and technical courses, socio cultural practices and educational studies. 
Table 6. The number of courses offered in 2012-2013 according to the classification of education training

\begin{tabular}{|c|c|c|c|c|c|c|c|c|c|c|c|c|}
\hline \multirow[b]{2}{*}{$\begin{array}{l}\text { Training areas } \\
\text { (FOET) }\end{array}$} & \multicolumn{2}{|c|}{ Total } & \multicolumn{2}{|c|}{$\begin{array}{l}\text { The ministry } \\
\text { and } \\
\text { Institutions }\end{array}$} & \multicolumn{2}{|c|}{ University } & \multicolumn{2}{|c|}{$\begin{array}{c}\text { Municipalit } \\
\mathbf{y}\end{array}$} & \multicolumn{2}{|c|}{$\begin{array}{l}\text { Confederatio } \\
\mathrm{n} \text { and union }\end{array}$} & \multicolumn{2}{|c|}{$\begin{array}{c}\text { Foundations } \\
\text { and } \\
\text { organization } \\
s\end{array}$} \\
\hline & 2012 & 2013 & 2012 & 2013 & $\begin{array}{l}201 \\
2\end{array}$ & $\begin{array}{l}201 \\
3 \\
\end{array}$ & 2012 & $\begin{array}{l}201 \\
3\end{array}$ & 2012 & 2013 & 2012 & 2013 \\
\hline Total & $\begin{array}{c}77 \\
715\end{array}$ & $\begin{array}{c}72 \\
321\end{array}$ & $\begin{array}{c}50 \\
003\end{array}$ & $\begin{array}{c}47 \\
104\end{array}$ & $\begin{array}{c}3 \\
203\end{array}$ & $\begin{array}{c}3 \\
805\end{array}$ & $\begin{array}{c}16 \\
169\end{array}$ & $\begin{array}{c}15 \\
841\end{array}$ & 685 & 276 & 7655 & 5295 \\
\hline General programs & 2754 & 2855 & 954 & 1258 & 437 & 331 & 415 & 538 & 28 & 15 & 910 & 724 \\
\hline Education & $\begin{array}{c}1572 \\
5\end{array}$ & 6054 & $\begin{array}{c}1394 \\
4\end{array}$ & 4535 & 332 & 442 & 359 & 258 & 85 & 9 & 1005 & 809 \\
\hline Humanities and art & $\begin{array}{c}1291 \\
7\end{array}$ & $\begin{array}{c}1119 \\
1\end{array}$ & 2556 & 1242 & 407 & 460 & 8580 & 8595 & 19 & 13 & 1355 & 881 \\
\hline $\begin{array}{l}\text { Liberal arts business } \\
\text { arts }\end{array}$ & $\begin{array}{c}1270 \\
3\end{array}$ & $\begin{array}{c}2009 \\
0\end{array}$ & 9555 & $\begin{array}{c}1758 \\
2\end{array}$ & 879 & 789 & 878 & 858 & 314 & 175 & 1067 & 685 \\
\hline $\begin{array}{l}\text { Science maths and } \\
\text { computer }\end{array}$ & 5615 & 4233 & 3181 & 1907 & 139 & 175 & 1902 & 1940 & 12 & 1 & 381 & 210 \\
\hline $\begin{array}{l}\text { Engineering producti } \\
\text { on and building }\end{array}$ & $\begin{array}{c}1089 \\
5\end{array}$ & $\begin{array}{c}1000 \\
5\end{array}$ & 9330 & 8353 & 223 & 305 & 884 & 959 & 45 & 10 & 413 & 378 \\
\hline $\begin{array}{l}\text { Agriculture and } \\
\text { veterinary }\end{array}$ & 721 & 334 & 496 & 197 & 83 & 52 & 76 & 68 & - & - & 66 & 17 \\
\hline Health and welfare & 4664 & 3744 & 2593 & 2535 & 398 & 515 & 408 & 351 & 11 & 9 & 1254 & 324 \\
\hline Services & $\begin{array}{c}1172 \\
0\end{array}$ & $\begin{array}{c}1380 \\
4\end{array}$ & 7374 & 9494 & 305 & 736 & 2667 & 2564 & 170 & 44 & 1204 & 1255 \\
\hline
\end{tabular}

Resources. TÜİK, NON FORMAL EDUCATION ACTIVITIES RESEARCH, 2009-2013

When we look at the Table 6 the most courses are conducted in the field of liberal arts, business and law with the rate of $\% 27,8$, according to the classification of training and education in 2012 the courses conducted in liberal arts, business and law rose from \% 16,3 to \% 28 in 2013 . The courses in service field of education dropped from \% 20,2 to \% 8,4 in 2013, humanities and arts dropped from \% 16,6 to \% 15,5 the courses in the field of engineering, manufacturing and construction dropped from \% 14 to $13,8.154$ 050 trainers took part in the courses. As the number of graduates increased in the field of education in 2013 the number of trainers also increased by \% 20,1 compared to the year 2012. According to fields; the most trainers took part in Liberal arts, business and law with \% 20,8, services with 19,9 and humanities and arts with 14,9. According to educational fields; the number of trainees who completed their non-formal education activities in the services sector with \% 27,6, \%20,9 with liberal arts, business and law and \% 12,5 with humanities and arts. The most training activities were held in İstanbul with 17 thousand 808 courses according to the cities, the most of the courses were held in istanbul with 17 thousand 808. Ankara is in the second place with 8 thousand 651, Antalya is in the third place with 'thousand 622, 2 thousand 332 courses in Adana and 2 thousand 039 courses in Bursa.

The fewest courses held in these cities. There were 151 courses in Muş, Ardahan 149, Iğdır 134 and Tunceli 75. When we look at the number of graduates according to the cities, there were 958 thousand 104 in İstanbul, 660 thousand in Ankara, 134 thousand 187 in Antalya 132 thousand 366 in izmir and 120 thousand 102 in Bursa. The most on educational practices were held in courses and private lessons. When we consider the type and character of the non-formal education according to institutions; \% 48,7 of the graduates are courses and private lessons , \% 38,9 are seminars, \% 12,4 are guided basic training at work. The certificate of participation was mostly taken from the courses and private lessons. In the courses and private lessons most certificate of participation were given by the ministries and associated institutions and municipalities. 
Table 7. The Seniority and Level of Education of Educators

\begin{tabular}{|c|c|c|c|c|c|c|c|}
\hline $\begin{array}{l}\text { Professional Employee } \\
\text { Distribution of Non-Formal } \\
\text { Educators }\end{array}$ & $\%$ & $\begin{array}{l}\text { The State of } \\
\text { Graduation } \\
\%\end{array}$ & $\begin{array}{l}\text { Teacher } \\
\%\end{array}$ & $\begin{array}{l}\text { Expert } \\
\text { Instructions } \\
\%\end{array}$ & $\begin{array}{l}\text { Temporarily } \\
\text { Employed Expert } \\
\text { Instructors \% }\end{array}$ & $\begin{array}{l}\text { Other } \\
\%\end{array}$ & $\begin{array}{l}\text { Total } \\
\%\end{array}$ \\
\hline & & Middle School & 0 & 33.3 & 11.3 & 0 & 7.7 \\
\hline$<5$ years & 29.7 & High School & 1.9 & 16.7 & 22.2 & 30 & 15.6 \\
\hline $6-10$ years & 13.6 & $\begin{array}{l}\text { Vocational } \\
\text { High School }\end{array}$ & 1.8 & 16.7 & 25 & 10 & 16.9 \\
\hline $11-15$ years & 17.4 & $\begin{array}{ll}\text { Two } & \text { Year } \\
\text { Degree } & \end{array}$ & 23 & 33.3 & 21 & 10 & 21.5 \\
\hline $16-20$ years & 20 & License & 69.9 & 0 & 16.1 & 40 & 33.8 \\
\hline$>21$ years & 18.5 & Grad School & 3.4 & 0 & 2 & 10 & 2.6 \\
\hline Missing & 0.8 & Missing & 0 & 33.3 & 0 & 30 & 1.2 \\
\hline
\end{tabular}

Resources: MEB Non Formal Education Institute , 2008

When we look at the Table 7 we see that \% 69,8 of the educators have graduate degree and \% 23,00 have university degree. It is understood that majority of the educators who are involved in public education courses are teachers .It is seen that majority of the master instructors and temporary master instructors are \% 33,3 from secondary schools in public education centers. Only \% 3,2 of the people who work in public education centers have master graduate degrees.

\subsection{The Problems in Public Education}

Since non-formal education system show a distinct feature from formal education, resources cannot be used efficiently and effectively (Türkoğlu, 2011). There are great disconnections between the non-formal and formal education institutions. They should be complementary to each other as they move but their activities are fully separated (Duman, 1991) And this leads inefficient use of resources.

When we look at the structure of the public education centers, the courses, the features of the participants and the division of the courses in the country, we can obviously understand a lot of problems. It is seen that the courses aren't divided in a balanced way in the country and the types of the trainers are also unbalanced. In order to talk about overall development, to increase the welfare of the citizens, to increase the job satisfaction and happiness, to reach a certain economic level it is not only necessary to spread the courses across the country but also it is necessary to make it available for every age group of people. The courses are more intense in areas where the jobs and industries are mainly concentrated. As we go towards the rural areas, we see a significant reduction in the number of courses and participants ( TÜİK, 2013).

In my research it can be seen that the number of institutions of public education centers is $\% 7,13$ and the number of trainers \% 54,64 among the institutions which have formal education system (TÜIK, 2013). This shows that a lot of things are tried to be done with a few institutions. This situations leads both keeping the organizations extremely busy and inadequate (Kurt, 2000). It is a fact that the number of public education centers are inadequate. While there are 30 students per class in private courses and study centers, there are 1268 trainees in public education centers (TÜIK, 2013). Because of overcrowding, enough importance is not given to the training of trainees which lowers the quality Therefore the graduates of the public education centers are not preferred by the employers ( Turkoğlu, 2011). People do not prefer these courses because of lack of space and generally courses are held in the basements and unhealthy buildings ( Türkoğlu, 2011).

The rapid changes in working life are forcing individuals to pursue continuous learning, innovation and continuous self-renewal ( Titrek, 2011). The identification of appropriate training needs of the labor market and creating training programs, the curriculum of the education, the quality of the trainers and lacking of practice are some of the reasons behind the quality problems ( Duman, 1991). The problem of quality is more felt with the public education. The general perception of the job market is that the education given by the PEC is low. Despite the free education of these institutions, they are not demanded in the job market ( Türkoğlu, 2011). If the public education leaves supply driven structure to demand driven structure may increase the demand for this situation ( Titrek, 2011). Labor market analysis is important in ensuring this. In fact it is obvious that all the vocational training activities should be 
customer centered. One reason for the negative connotations associated with the public education centers is that very little is known by the public ( Türkoğlu, 2011).

A major obstacle most countries encounter in making better public education programs are that lacking of launching a new extended programs in a wide range of planning and overall management, lacking of well-trained sufficient full time professional staff ( Lowe, akt Toker, 1985). The major deficiency PEC is the fact that there are few or no professional students in them (Türkoğlu, 2011). Although it is a requirement to get necessary education and qualifications because of lacking of such trainers, the teachers who come from primary and secondary schools are appointed ( Bülbül, 1987). In order to prevent the loss of value time and energy because of while executing the same services or taking it to the department; it is a must to provide integration between the sectors ( Türkoğlu, 2011). Because the educators are expert educators or temporary expert educators and not having the stuff who are expert in their fields, public training courses cannot go beyond the practice and generally stay at the basic level. The number of temporary stuff is a fairly high in PEC. This leads problems in owning the business and being part of the job (Türkoğlu, 2011). Since the amount of the money allocated to non-formal education is low, PEC demand money from the trainers and this action effects the attendance negatively. ( Türkoğlu and Uça, 2011). It is seen in the research that the budget allocated to PEC is low. \%1, 89 of the budget is given from the budget of education ( TÜIIK, 2013). The budget allocated to PEC must be increased.

Table 8. The amount and distribution of education expenditure of Turkey according to it's service providers

\begin{tabular}{lcc}
\hline & Numbers & \% \\
\hline Total & 20155207669 & 100,00 \\
Formal Education & 18682430396 & 92,69 \\
$\quad$ Non-formal Education & 373953093 & 1,86 \\
In services job training & 43971612 & 0,22 \\
Debt Services & 105067038 & 0,52 \\
Private Training Centers & 623191660 & 3,09 \\
Research \& Development Expenditures & 49182221 & 0,24 \\
High School Graduates, Preparing for University & 277411649 & 1,38 \\
\hline
\end{tabular}

Resources. TÜIK, 2012.

In order to develop common training activities undertaken by various institutions in Turkey, one of the major obstacles which are financial obstacles must be overcome (Titrek, 2013).

\section{The Conclusion and Recommendations}

All of this statistical information and other findings revealed the following results. It has been seen that the number of institutions of PEC are inadequate, inappropriate buildings and courses are opened the activities are carried out in inadequate places. In order to eliminate this situation, suitable centers and classrooms must be built by the government or private enterprise. It is necessary to improve the physical facilities of the classrooms used by public education ( Türkoğlu, 2011). The number of public education centers must be increased. They must be opened in every town even in villages. Inter-regional disparities $\mathrm{d}$ be eliminated. The number of the courses must be increased. The number of trainees should be less so that they can get a quality education. There should be not only vocational courses but also there should be courses for hobbies socio cultural courses (Türkoğlu, 2011). Especially traditional crafts courses should be opened (Okçabal, 1989).

The number of trainees per class in private centers is 10 , in private tutoring 32 . In overall Turkey the number of students per class is 91. But in Public education centers 1268 students per class (TÜiK, 2013). In such a dense place quality of education cannot be done and it won't serve the purpose of the opened courses. The number of the courses must be increased urgently and they should be taken to at least overall of Turkey. Otherwise; there will be no benefit of PEC. The same situation also can be seen in the number of staff as well. 1,77 trainers work per class in public education centers while the number is 49,61 in private courses ( TÜiK, 2013). The number of necessary staff and teaching staff should be increased in public education centers ( Türkoğlu, 2011).

When analyzing the ratio of the number of the courses and the ratio of population in the country we see that more courses are opened where the industries and job opportunities are intensive and less courses are opened in southeast Anatolia and east Anatolia (TÜiK, 2013). No matter where the region is public education centers must be opened everywhere. More importance must be given to the places where 
industrial facilities haven't developed. The same situation is valid for the provinces as well. \% 40,21 of the courses and the \% 53,74 of the trainers are in İstanbul Ankara and İzmir ( TÜİK, 2013). This is a really unstable distribution. The courses should be opened so that every citizen can benefit from them. There are a lot of differences in terms of human resources, industry, natural resources, transportation and employment in turkey. Non formal education activities should be planned by taking into account of the differences and local administrators should be made take active roles in them (Coşkun, 2009). It is obvious that the distribution of the courses are unbalanced throughout the regions and cities and the people cannot take advantage of these courses equally ( TÜİK, 2013). These differences between the provinces should be eliminated.

The people who live in those places depriving of employment should be made get the same education, should get the certificates according to their skills. Necessary analysis should be made according to the situation of the region and courses should be opened and should meet the demands of the employers and citizens. The integration of these citizens must be ensured ( Türkoğlu, 2011). Collaboration with the industrialists should be provided, their needs should be identified and the courses which will be opened should meet the needs of these institutions. Therefore; the graduates must find a job. The courses should spread across the country; every citizen should be provided to benefit from these activities.

Public education centers should be opened not only for job opportunities but also for socio cultural needs and hobbies. The opportunities of developing their skills should be given to the people ( MEB, 2014). The new studies which will be made in the field of education are vital in terms of vocational and socio technical education (Özoğul, 2003). One of the most urgent problem Turkey should solve is the problem of employment. Studies should be done both to gain qualifications to unskilled labor and new regulations should be conducted to encourage the unemployed population to get the education in the needed areas ( Coşkun, 2009). Public education centers should give up the idea of where housewives spend their free time. Hobby centers or public centers must be opened for this goal instead. Public education centers should be transformed into institutions which respond to the modern needs, the needs of the participants should be taken into account and the different experiences of them should be benefitted from in the development of adult education (Kılıç,1983).

The interests of the adult students should be awaken, their confidence should be increased, their active participation should be ensured at every stage of the educational process, such as program development, implementation and evaluation programs and adult education activities should be planned in a way that make changes in which they work and live. Especially the incentives and obstacles affecting the education and learning process must be determined (MEB, 2006). More emphasis should be given for girls and women to benefit from formal and non-formal education activities ( Coşkun, 2009). The staff working in PEC is very low. $3 / 1$ of the staff consist of secondary school graduates ( TÜIK, 2013). This situation lowers the quality of courses and this causes them to professional staff should be available in public education centers. Special departments must be opened for the people who PECs and there people should be made work at PECs. Managers should be trained in the same way as well. It must be prevented to become administrators from any educational institutions and the people who trained in the field of education become experts must be selected as managers ( Türkoğlu, 2011).

Administrators working in public education centers should be chosen from among the people who are trained in law and management ( Titrek, 2011). The people working in PECs should be educated in the fields of employee relations and human relations social communication and social skills. The master trainers should at least be high school graduate and must have taken some training courses. There are not enough staff at the PECs. The classes are conducted by the teachers appointed from outside. Public training courses are conducted by the people who are not specialized in this regard (Türkoğlu,2011). The need of the people should be provided and collaborate with the universities. Adequate norm should be given to PEC, these norms should be assigned. In the absence of sufficient staff, priority should be given to university graduates and master trainers should be employed (Türkoğlu, 2014). The participation rate to non-formal education is very low compared to 27 European Union countries. For a country like Turkey which is a combination of traditional and modern, non-formal education has started to become more important with the effect of EU (Titrek, 2013). \% 12,5 of the adults ( 25-64) in European Union countries are set to participate in the non-formal education (DPT, 2009). In Turkey this rate is \% 4.36 (TÜIK, 2013). The participation rate to non-formal European countries (Eurostat 2012) It is necessary to increase the number of participation to non-formal education in our country is $\% 9,5 \mathrm{in} \mathrm{EU}$

\section{References}


Abukari, A. (2005). Conceptualizing Lifelong Learning: A Reflection on Lifelong Learning at Middlesex University (UK) and Lund University (Sweden). European Journal of Education, 40(2), 142-154.

Ada, S. (2002). Determination of the applications of the female trainees joined to the courses related to the environment and human health. (Marmara University /Atatürk Faculty of Education, Educational Science Magazine.

Akbaş, 0., M. Özdemir S. (2002). Lifelong Learning in European Union, taken from the address http://yayim.meb.gov.tr/journals/155-156/akbas.htm

Aksoy, M. (2008). Lifelong Learning and Career Planning Guidance Policies

Aziz, A. (1975).Place and Importance of Adult Educatıon, Sevinç Printing, 20-21.

Bağcl, Ş. E. (2007 Lifelong Learning Policies in European Union Countries: A comparative study on Germany Denmark and Turkey. An unpublished graduate thesis ( University of Ankara / Institute of Educational Sciences Departments of Public Education, Ankara

Bülbül, S. (1987). The Non Formal Educatıon in Our World and Country- Non Formal Educatıon, Ted XI Education Appointment, TED Science Series,27.

Celep, C. (2003). Public Education, Ankara,Anı Publishing.

Coşkun,Y (2009). The investigation of university student's lifelong learning inclınatıons according to some variables, Unpublished PDH Thesis Hacettepe University, Ankara.

Demirel, Ö. (1987). Terms of Educatıon, Şafak Printing, Ankara 1987,186.

Diker-Coşkun, Y. (2009). Examining the lifelong learning of university students in terms of some variables unpublished doctoral thesis. University of Hacettepe/ Institute of Social Sciences, Ankara.

DPT, (2009).Lifelong Learning Strategy Document, Retrieved February, 25,2013, from http://mesbil.meb.gov.tr/genel/hayat\%20boyu\%20\%C3\%B64\%9Frenme\%20dokuman.pdf

Duman, A. (1991). Problems En Adult education in Turkey, Education and Science Journal,15, 43-46.

Eurostat (2012). Lifelong Learning. Retrieved February 25, 2013 from http://epp.eurostat.ec.europa.eu/tgm/graph.do?pcode=tsds440\&language=en

Fidan, N. and ERDEM, M. (1991). Introduction to Education, Peryal Printing, 225.

Kurt, İ. (2000).Adult education Ankara Nobel publishing.

Lowe, S. Translatıng: Oguzkan T. (1985).Overview of adult Educatıon, UNESCO, T.M.A Broadcasts, 23.

MEB, (2014).The Regulations of Non Formal Education Institutions, Ankara, Ministry of Education. Ministry of Education Institute of Public Education (2008) ), it was taken from the address in the date of 08/08/2015 http://yee.meb.gov.tr

Okçabol, R. (1996)."Public Education second printing Der Publishing it was taken from the address in the

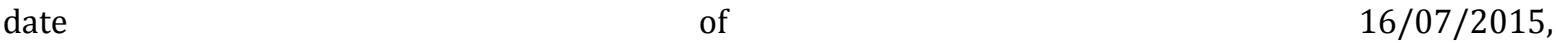
http://www.kitapvekitap.com/kitap/der-yayinlari/rifat-okcabol/halk-egitimi.html.

Özoğul, S. (2003).A work program for creating models of general knowledge applied in public education centers: Master's Thesis , Education Faculty of Marmara University.

Taylor, R. (2001). Lifelong Learning in Higher Education in Western Europe. DVV International Adult Education and Development (56).

Titrek, O.and Poyraz, H. (2013). The development of Life Long Learning in Turkey, Sakarya University, Faculty of Education.

TÜİK, The Research of Non Formal Education Activities, 2009-2013.

Türkoğlu, A. ve Uça, S. (2011).Public Education in Turkey'I Historical Development, Problems and Solutions Adnan Menderes University Education Faculty, Journal of Educational Sciences 2,48-62. 